J. Amer. Soc. Hort. ScI. 121(1):69-76. 1995.

\title{
Whole-plant Response of Six Poinsettia Cultivars to Three Fertilizer and Two Irrigation Regimes
}

\author{
Ursula Schuch \\ Department of Botany and Plant Sciences, University of California, Riverside, CA 92521 \\ Richard A. Redak and James Bethke \\ Department of Entomology, University of California, Riverside, CA 92521 \\ Additional index words. water stress, chlorophyll content, SPAD chlorophyll meter, soluble proteins, transpiration
}

\begin{abstract}
Six cultivars of poinsettia (Euphorbia pulcherrima Wind.), 'Angelika White', 'Celebrate 2', 'Freedom Red', 'Lilo Red', 'Red Sails', and 'Supjibi Red' were grown for 9 weeks during vegetative development under three constant-feed fertilizer treatments, 80,160, or $240 \mathrm{mg}$ N/liter and two irrigation regimes, well-watered (high irrigation) or water deficient (low irrigation). Plants fertilized with 80 or $240 \mathrm{mg}$ N/liter were $10 \%$ to $18 \%$ shorter, while those fertilized with $160 \mathrm{mg}$ N/liter were $25 \%$ shorter with low versus high irrigation. Leaf area and leaf dry weight increased linearly in response to increasing fertilizer concentrations. Low irrigation reduced leaf area, leaf, stem, and shoot dry weight 3670 to $41 \%$. Cultivars responded similarly to irrigation and fertilizer treatments in all components of shoot biomass production and no interactions between the main effects and cultivars occurred. Stomatal conductance and transpiration decreased with increasing fertilizer rates or sometimes with low irrigation. Highest chlorophyll contents occurred in leaves of 'Lilo Red' and 'Freedom Red'. Leaves of plants fertilized with $80 \mathrm{mg}$ N/liter were deficient in leaf $\mathrm{N}$ and had $40 \%$ to $49 \%$ lower leaf chlorophyll content compared to plants fertilized with 160 or $240 \mathrm{mg}$ N/liter. Irrigation had no effect on leaf $\mathrm{N}$ or chlorophyll content. At the end of the experiment leaves of 'Supjibi Red' and 'Angelika White' contained higher concentrations of soluble proteins than the other four cultivars.
\end{abstract}

Fertilization and irrigation management are important components of producing a healthy crop. Applying liquid fertilizer at a constant rate with each irrigation has become a popular and economical practice for many poinsettia growers (Ecke et al., 1990). The advantage of such a program is ease of application, which supplies nutrients constantly at desired levels, while excess nutrients may be leached from the media. However, excess nutrients in the leachate are wasted.

About $250 \mathrm{mg} \mathrm{N} /$ liter are recommended for constant fertigation of poinsettias (Ecke et al., 1990). In recent years fertilizer recommendations have been reevaluated because nitrate leaching from intensive greenhouse production has become a major environmental concern (Biernbaum, 1992; Cabrera et al., 1993; Hershey and Paul, 1982). Poinsettias grown with a solution of $200 \mathrm{mg} \mathrm{N} / \mathrm{liter}$ produced large plants with excessive foliar $\mathrm{N}$ levels (Tayama and Carver, 1992). Acceptable growth in poinsettias was achieved by lowering fertilizer applications via subirrigation to a constant rate of $125 \mathrm{mg} \mathrm{N} /$ liter (Rose and White, 1994), indicating that poinsettias can be grown successfully with $50 \%$ less fertilizer than is currently recommended.

Irrigation is a critical management tool when coupled with constant liquid fertilization to manipulate electrical conductivity (EC) levels of the growing medium. Poinsettias grown with constant application of 100, 200, or $400 \mathrm{mg} \mathrm{N} /$ liter and leaching fractions from 0 to 0.5 were of acceptable quality, but plant height and dry weight generally increased with decreasing root media EC (Yelanich and Biernbaum, 1993). Similar media EC, plant height, and fresh weight were produced with $100 \mathrm{mg} \mathrm{N} /$ liter and 0.2 to 0.3 leaching fraction, or with 200 or $400 \mathrm{mg}$ N/liter, each with 0.4 to

Received for publication 1 May 1995. Accepted for publication 6 Sept. 1995, We express appreciation to Douglas Holt for technical assistance. We grateful I y acknowledge financial support from the California Association of Nurserymen and donation of the poinsettia cuttings from Paul Ecke Ranch, Encinitas, Calif. Use of tradenames does not imply endorsement of products named nor criticism of similar products not mentioned. The cost of publishing this paper was defrayed in part by the payment of page charges. Under postal regulations, this paper therefore must be hereby marked advertisement solely to indicate this fact.
0.6 leaching fraction. The 2- or 4-fold $\mathrm{N}$ application of the latter two treatments compared to the $100 \mathrm{mg} \mathrm{N} /$ liter treatment were wasted. Hershey and Paul ( 1982) reported that more N was lost through leaching at higher application rates of liquid fertilizer when the same leaching fraction was used. Poinsettias fertilized with $300 \mathrm{mg} \mathrm{N} /$ liter with leaching fractions ranging from $\mathrm{O}$ to 0.4 showed no differences in growth, but accumulated high EC levels in the media, particularly at low leaching fractions $(\mathrm{Ku}$ and Hershey, 1991).

Many floriculture crops, including poinsettias, are treated with growth retardants to achieve the desired shorter and compact canopy for container-grown plants (Larson, 1992). Water stress reduces plant growth and leaf area (Kramer, 1983) and may be used as a strategy to control stem elongation (Röber and Hafez, 1981). However, if water deficits are too severe, stomatal closure, reduced photosynthesis, or even permanent chloroplast damage can occur (Kramer, 1983).

The primary objective of this study was to evaluate six poinsettia cultivars for their vegetative growth and physiological characteristics in response to three fertilizer concentrations and two irrigation regimes. Additionally, as the impact of water stress and nitrogen fertilization on populations of phytophagous insects can be quite profound (Mattson and Haack, 1987a, 1987b; White, 1976, 1984), we also examined the impact of these factors on the potential suitability of poinsettia as an insect host plant. Host plant suitability to insects was estimated by the quantity of foliar soluble protein. Previous studies suggested higher concentrations of foliar protein to be associated with increased preference of such plants to phytophagous insects (Bentz et al., 1995; White, 1984).

\section{Materials and Methods}

Rooted poinsettia cuttings were transplanted individually in pots (1360 ml) with UC \#3 mix (Matkin and Chandler, 1957) on 14 May 1994. The six cultivars used in this study were 'Angelika White', 'Celebrate 2', 'Freedom Red', 'Lilo Red', 'Red Sails', and 'Supjibi Red'. Plants were grown in a double-poly greenhouse 
Table 1. Analysis of variance for plant height measured 3, 5, 6, 7, and 9 weeks after three fertilizer and two irrigation treatments were imposed on six poinsettia cultivars.

\begin{tabular}{|c|c|c|c|c|c|}
\hline & \multicolumn{5}{|c|}{ Weeks after treatments started } \\
\hline & 3 & 5 & 6 & 7 & 9 \\
\hline$\overline{\text { Fertilizer }(\mathrm{F})}$ & NS & $* * *$ & $* * *$ & $* * *$ & **** \\
\hline Irrigation (I) & $* * *$ & $* * *$ & $* * *$ & $* * *$ & $* * *$ \\
\hline $\mathrm{F} \times \mathrm{I}$ & $* *$ & $* * *$ & $* *$ & $* * *$ & $* *$ \\
\hline Cultivar (C) & $* * *$ & $* * *$ & $* * *$ & $* * *$ & $* * *$ \\
\hline $\mathrm{F} \times \mathrm{C}$ & NS & NS & NS & NS & NS \\
\hline $\mathrm{I} \times \mathrm{C}$ & NS & NS & NS & NS & NS \\
\hline $\mathrm{F} \times \mathrm{I} \times \mathrm{C}$ & NS & NS & NS & NS & NS \\
\hline \multicolumn{6}{|c|}{ Single degree of freedom contrasts } \\
\hline F linear & NS & $* * *$ & $* * *$ & $* * *$ & ** \\
\hline F quadratic & NS & NS & NS & NS & NS \\
\hline $\mathrm{I} \times \mathrm{F}$ linear & NS & NS & NS & NS & NS \\
\hline $\mathbf{I} \times \mathrm{F}$ quadratic & $* *$ & $* * *$ & $* * *$ & $* * *$ & $* *$ \\
\hline
\end{tabular}

located at the University of California at Riverside. The range of average day/night temperatures was between 27 to $32 \mathrm{C}$ and 19 to $24 \mathrm{C}$, with average daily relative humidity between $44 \%$ and $85 \%$. Poinsettias were grown as single stem plants and were provided only with natural daylight.

For the first 6 weeks plants were irrigated with a $150 \mathrm{mgN} /$ liter solution (Miracle Grow; Sterns Miracle Gro Products, Port Washington, N.Y.). Individual heavy weight emitters were placed on the media in each pot and water was delivered with a drip system. Distribution uniformity of the irrigation system was between 0.93 and 0.96 at the beginning of the experiment.

Six treatments (three concentrations of $\mathrm{N}$ fertilizer by two levels of irrigation) were started on 2 July and continued until final harvest on 1 Sept. Plantex 17-5-19 Poinsettia Fertilizer (Plantco Inc., Brampton, Ont., Canada) was injected continuously (model D 1-16; Dosatron Intl., France) into the irrigation water at 80,160 , or $240 \mathrm{mg}$ N/ liter. Actual nitrate and ammonia concentrations of the irrigation water were monitored weekly with a nitrate electrode (model 93-07) (Orion, Boston) and an ammonia electrode (model 95-12), respectively.

Irrigation treatments consisted of 24-or 48-sec applications (120 or $240 \mathrm{ml}$ water per pot) every other day. To minimize runoff, half of the irrigation water was applied at $0800 \mathrm{HR}$, and the second half at $1000 \mathrm{HR}$. Plants receiving $240 \mathrm{ml}$ (high irrigation) were well-watered and never displayed any signs of wilting; plants receiving the deficit irrigation of $120 \mathrm{ml}$ (low irrigation) usually started to wilt between irrigation cycles.

Fig. 1. Plant height of poinsettia grown for 9 weeks under three fertilizer by two irrigation regimes (bars indicate \pm 1 standard error), Means are averages of six cultivars.
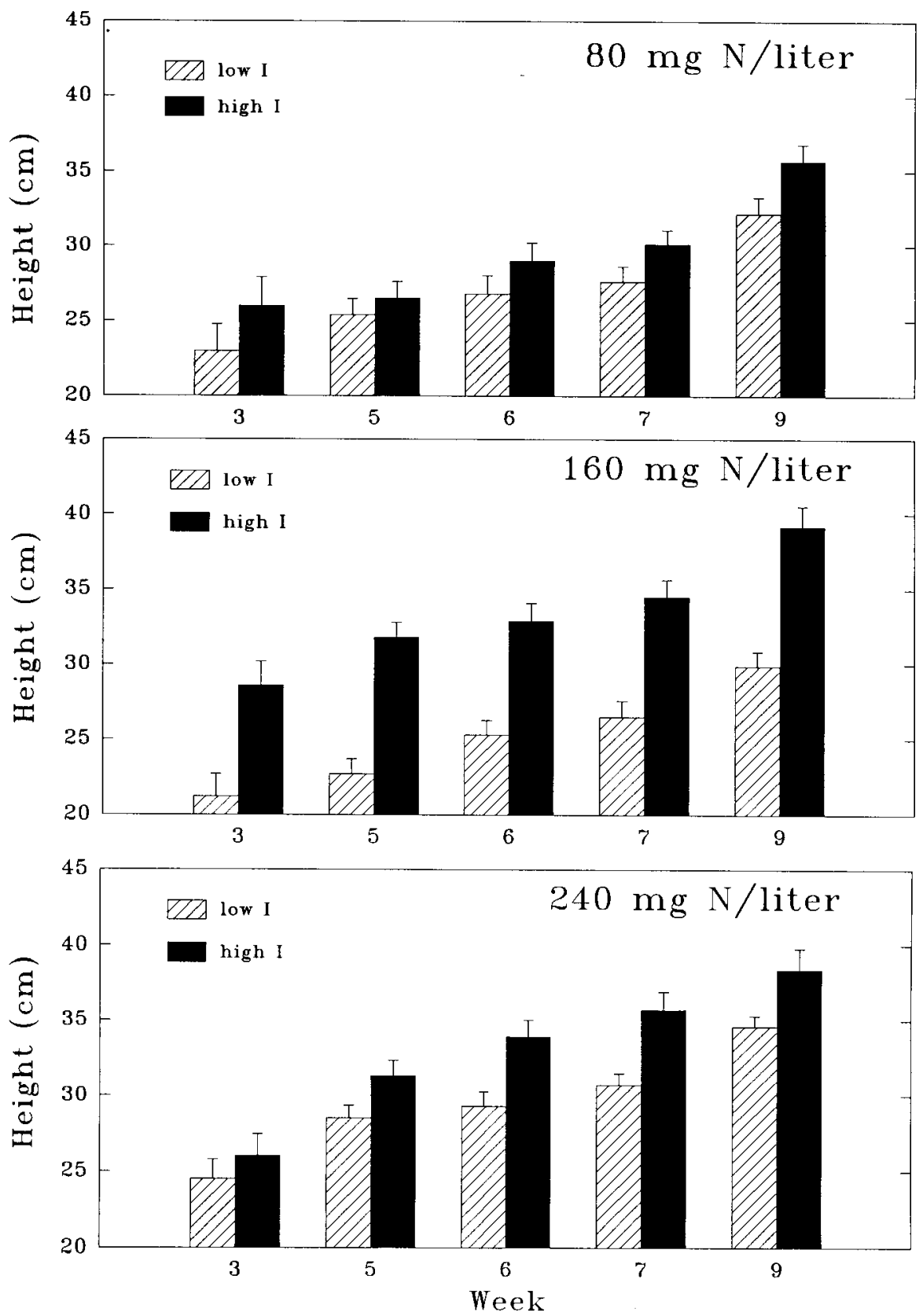


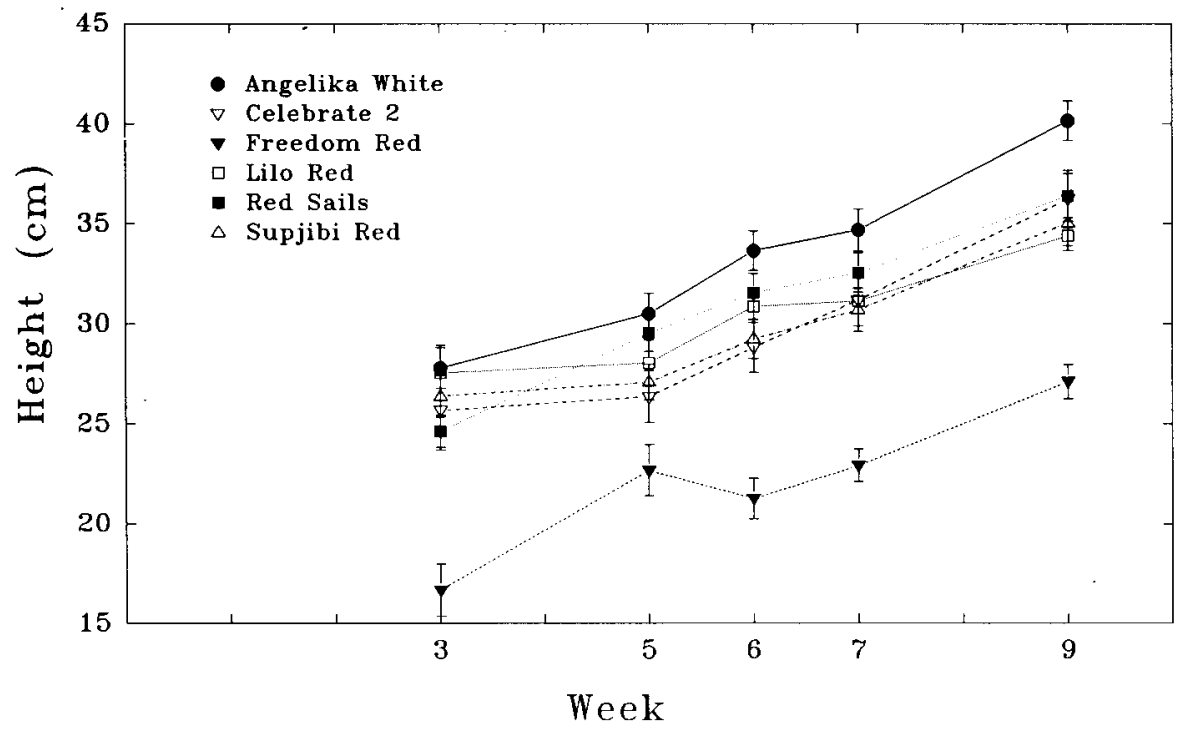

Fig. 2. Plant height of six poinsettia cultivars grown for 9 weeks under three fertilizer by two irrigation regimes, averaged over fertilizer and irrigation regimes (bars indicate \pm 1 standard error)

to $30 \mathrm{~h}$ after the most recent irrigation. Relative chlorophyll content of the most recently fully expanded leaves also was measured at these dates with an in situ SPAD-502 chlorophyll meter (Minolta, Japan). Actual chlorophyll content of leaf disks with a known SPAD reading was determined according to the method of Bruinsma (1963). Standard regression curves for chlorophyll content as a function of SPAD readings were calculated for each poinsettia cultivar.

Plant height was measured from the media surface to the shoot apex on the dates above and at final harvest. On 1 Sept., plants were harvested and leaves were

Actual volumes of irrigation solution applied were measured once a week for 6 weeks.

Stomatal conductance and transpiration were measured with a steady-state porometer (LI-1600; LI-COR, Lincoln, Neb.) on 23 July and on 4,12, and 18 Aug. Measurements were taken about 26 counted, leaf area was measured with a LI-3100 leaf area meter, and leaf and stem dry weight 'were determined. Leaf $\mathrm{N}$ concentration of the most recently fully expanded leaves was determined with the Kjeldahl method. Soluble proteins of these same leaves were determined according to the procedure of Jones et al. (1988).

Table 2. Number of leaves, leaf area, and leaf, stem, and shoot dry weight of six poinsettia cultivars grown at three fertilizer and two irrigation treatments from 2 July until 1 Sept.

\begin{tabular}{|c|c|c|c|c|c|}
\hline & \multirow{2}{*}{$\begin{array}{c}\text { No. } \\
\text { of } \\
\text { leaves }\end{array}$} & \multirow{2}{*}{$\begin{array}{l}\text { Leaf } \\
\text { area } \\
\left(\mathrm{cm}^{2}\right)\end{array}$} & \multicolumn{3}{|c|}{$\begin{array}{l}\text { Dry wt } \\
(\mathrm{g})\end{array}$} \\
\hline & & & Leaf & Stem & Shoot \\
\hline \multicolumn{6}{|c|}{ Fertilizer (mg N/liter) } \\
\hline 80 & 102 & 2708 & 12.0 & 8.2 & 20.2 \\
\hline 160 & 108 & 3394 & 13.6 & 5.7 & 19.4 \\
\hline 240 & 118 & 3947 & 15.1 & 6.8 & 22.0 \\
\hline \multicolumn{6}{|l|}{ Irrigation (ml/pot) } \\
\hline 120 & 91 & 2592 & 10.5 & 5.1 & 15.6 \\
\hline 240 & 127 & 4107 & 16.8 & 8.7 & 25.5 \\
\hline \multicolumn{6}{|l|}{ Cultivar } \\
\hline Angelika White & $157 a^{7}$ & $4477 \mathrm{a}$ & $15.2 \mathrm{a}$ & $8.3 \mathrm{a}$ & $23.5 \mathrm{a}$ \\
\hline Celebrate 2 & $92 \mathrm{c}$ & $2991 \mathrm{bc}$ & $12.0 \mathrm{c}$ & $6.6 \mathrm{~b}$ & $18.5 \mathrm{~b}$ \\
\hline Freedom Red & $84 \mathrm{c}$ & $2765 c$ & $12.6 \mathrm{bc}$ & $5.9 \mathrm{~b}$ & $18.5 \mathrm{~b}$ \\
\hline Lilo Red & $129 \mathrm{~b}$ & $3518 \mathrm{~b}$ & $15.0 \mathrm{a}$ & $7.3 \mathrm{ab}$ & $22.3 \mathrm{a}$ \\
\hline Red Sails & $102 \mathrm{c}$ & $3435 \mathrm{~b}$ & $14.6 \mathrm{ab}$ & $7.1 \mathrm{ab}$ & $21.7 \mathrm{~b}$ \\
\hline Supjibi Red & $92 \mathrm{c}$ & $2912 b c$ & $12.3 b c$ & $6.2 \mathrm{~b}$ & $18.5 \mathrm{~b}$ \\
\hline \multicolumn{6}{|l|}{ Significance of $F$ test } \\
\hline Fertilizer $(\mathrm{F})$ & NS & $*$ & NS & NS & NS \\
\hline Irrigation (I) & $* * *$ & $* * *$ & $* * *$ & $* * *$ & $* * *$ \\
\hline$F \times I$ & NS & NS & NS & NS & NS \\
\hline Cultivar (C) & $* * *$ & $* * *$ & $* *$ & * & ** \\
\hline $\mathrm{F} \times \mathrm{C}$ & NS & NS & NS & NS & NS \\
\hline $\mathrm{I} \times \mathrm{C}$ & NS & NS & NS & NS & NS \\
\hline $\mathrm{F} \times \mathrm{I} \times \mathrm{C}$ & NS & NS & NS & NS & NS \\
\hline \multicolumn{6}{|c|}{ Single degree of freedom contrasts } \\
\hline$F$ linear & NS & $* *$ & * & NS & NS \\
\hline$F$ quadratic & NS & NS & NS & NS & NS \\
\hline $\mathrm{I} \times \mathrm{F}$ linear & NS & NS & NS & NS & NS \\
\hline $\mathrm{I} \times \mathrm{F}$ quadratic & NS & NS & NS & NS & NS \\
\hline
\end{tabular}

${ }^{\mathrm{T}}$ Means within a column followed by different letters are significantly different at $P<0.05$, Duncan's multiple range test.

${ }_{\mathrm{NS}, *, *, *, *+*}$ Nonsignificant or significant at $P<0.05,0.01$, or 0.001 , respectively. 
Table 3. Stomatal conductance and transpiration of six poinsettia cultivars grown at three fertilizer and two irrigation treatments from 2 July until 1 Sept.

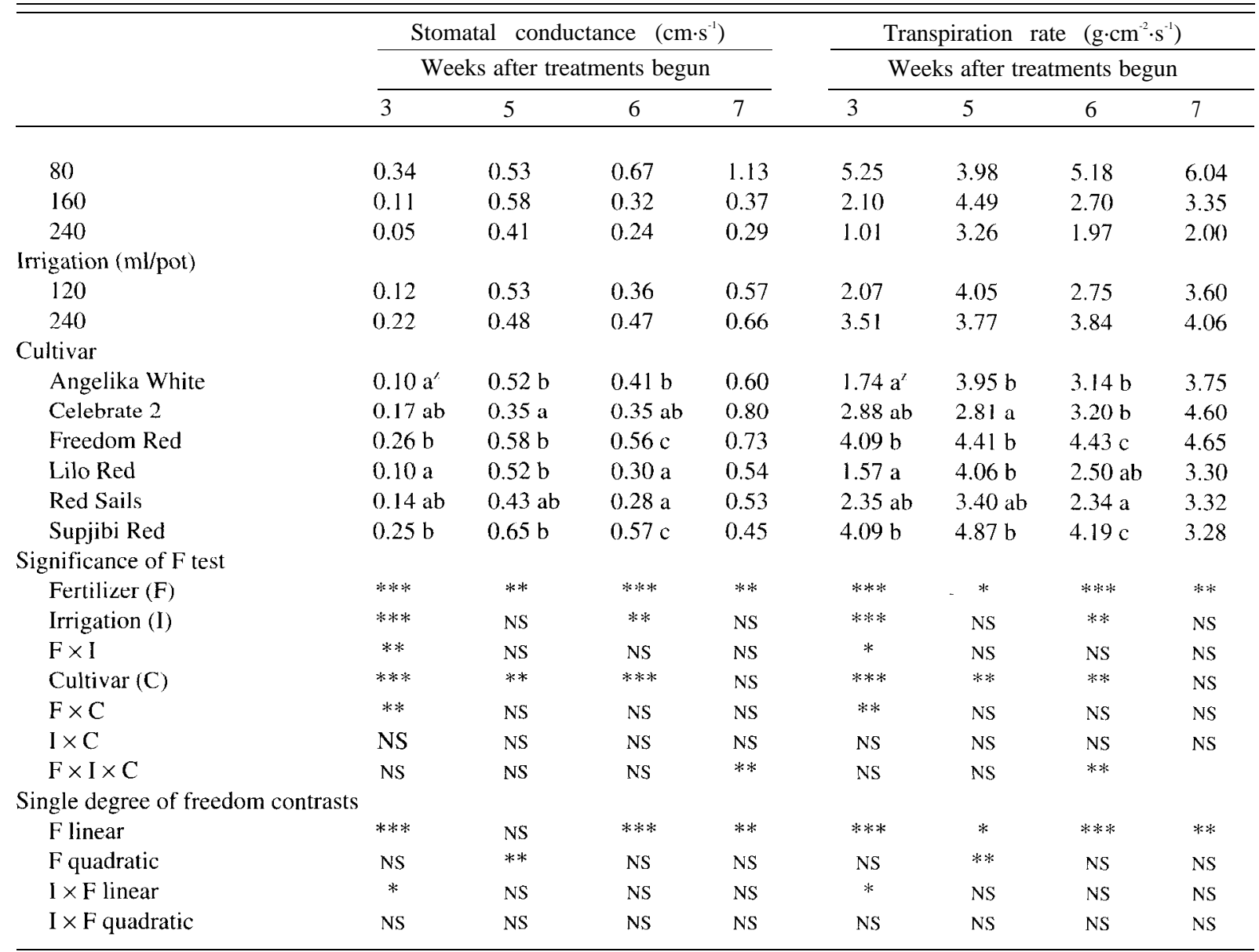

${ }^{\overline{ }}$ Means within a column followed by different letters are significantly different at $P<0.05$, Duncan's multiple range test. ${ }_{\text {Ns., }, *, *, * * *}$ Nonsignificant or significant at $P<0.05,0.01$, or 0.001 , respectively.

The experimental design was a split plot in a randomized split block with four blocks. The treatment design was a $3 \times 2 \times 6$ factorial with three $\mathrm{N}$ fertilizer concentrations by two irrigation treatments by six cultivars. Fertilizer and irrigation were the two main plot factors and cultivar was the subplot factor. Data were analyzed with analysis of variance and single degree of freedom contrasts where appropriate. Mean separation of cultivars was calculated with Duncan's multiple range test if $F$ test for cultivars was significant. Stepwise regression was used to correlate chlorophyll content to SPAD readings (SAS Inst., Cary, N.C.).

\section{Results}

Plant height was significantly influenced by a fertilizer-irrigation interaction and by cultivar main effects (Table 1, Figs. 1 and 2). Low irrigation and the $160 \mathrm{mg} \mathrm{N} /$ liter resulted in the shortest plants, while well-watered plants were the tallest. Plants fertilized with 80 or $240 \mathrm{mg} \mathrm{N} / \mathrm{liter}$ were $10 \%$ to $18 \%$ taller when watered with high versus low irrigation throughout the experiment. Cultivar specific differences were found for plant height throughout the experiment with 'Freedom Red' as the shortest cultivar, around 8 $\mathrm{cm}$ shorter than the other cultivars (Fig. 2). 'Angelika White' was the tallest cultivar during the second half of the experiment.

Treatment effects from irrigation dominated all components of shoot biomass production. Low versus high irrigation significantly reduced leaf area, leaf, stem and shoot dry weight $36 \%$ to $41 \%$, while leaf number was reduced by $28 \%$ (Table 2). A positive linear fertilizer effect on leaf area and leaf dry weight was detected with single degree of freedom contrasts. Cultivars responded similarly to irrigation and fertilizer treatments in all components of shoot biomass production as no interactions between treatments and cultivars were found (Table 2). 'Angelika White' and 'Lilo Red' produced plants with the largest shoot biomass while 'Celebrate 2', 'Freedom Red', and 'Supjibi Red' produced less biomass. 'Red Sails' ranked between those two groups.

Stomatal conductance and transpiration decreased with increasing fertilizer rates (Table 3). Low irrigation was associated with lower conductance and transpiration 3 and 6 weeks after water treatments began (Table 3). Highest stomatal conductance and transpiration were measured on leaves from cultivars 'Freedom Red' and 'Supjibi Red'. We also observed that the natural diaheliotropism of leaves was altered when plants under deficit irrigation developed epinasty as the experiment progressed.

Chlorophyll content measured by extraction from leaf disks corresponded closely to that determined by the in situ chlorophyll meter (Fig. 3). Chlorophyll content measurements for each cultivar were taken from foliage ranging from chlorotic to dark green. The relationship between destructive and in situ chlorophyll content measurements for cultivars 'Freedom Red' and 'Red Sails' were similar and best described with a quadratic regression. Similar relationships with a linear and quadratic component were determined for 'Celebrate 2' and 'Lilo Red', while a linear regres- 
sion produced the best fit for 'Angelika White' and 'Supjibi Red'.

Highest chlorophyll content was observed in 'Lilo Red' followed by 'Freedom Red' for all four sampling times (Table 4). The other cultivars were not consistent in their relative ranking based on chlorophyll content. Linear and quadratic increases in chlorophyll content were observed with increasing fertilization. At week 5 , chlorophyll content was $40 \%$ and $49 \%$ higher for plants at the medium and high fertilization level, respectively, compared to plants at the low level (Table 4). A cultivar-fertilizer interaction was found at week 7 when chlorophyll content of 'Supjibi Red' increased linearly over the fertilizer treatments while chlorophyll content of the other cultivars increased from 80 to $160 \mathrm{mg}$ N/liter and then remained stable or decreased at $240 \mathrm{mg} \mathrm{N} /$ liter (Fig. 4). Irrigation had little influence on leaf chlorophyll content (Table 4).

Leaf $\mathrm{N}$ concentration responded linearly and quadratically to increasing fertilizer, with overall means of $3.66 \%, 4.40 \%$, and $4.59 \%$, for the low, medium, and high fertilizer treatments, respectively. Leaf $\mathrm{N}$ concentration also showed an interaction between fertilizer treatments and cultivar at the end of the experiment, while irrigation had no effect throughout the experiment. With increasing $\mathrm{N}$ in the fertilizer solution, leaf $\mathrm{N}$ increased linearly for 'Celebrate 2', 'Lilo Red', and 'Angelika White' (Fig. 5). Leaf N in 'Supjibi Red' and 'Red Sails' increased when fertilizer was increased from 80 to $160 \mathrm{mg}$ N/liter and then remained constant when $\mathrm{N}$ was increased to $240 \mathrm{mg} / \mathrm{liter}$. 'Freedom Red' showed the strongest response to an increase in fertilizer from 80 to $160 \mathrm{mg}$ N/liter with a $38 \%$ increase in leaf $\mathrm{N}$ to $4.8 \%$, the highest leaf Nat this fertilizer treatment. At $240 \mathrm{mg} \mathrm{N} /$ liter, leaf $\mathrm{N}$ of 'Freedom Red' dropped to $4.6 \%$.

Soluble proteins in poinsettia leaves differed between cultivars. Leaves of 'Supjibi Red' and 'Angelika White' contained 0.26 and $0.24 \mathrm{mg} \cdot \mathrm{g}^{-1}$ dry weight, respectively, while leaves of the other four cultivars contained less soluble proteins, ranging from 0.21 to $0.19 \mathrm{mg} \cdot \mathrm{g}^{-1}$ dry weight. Nine weeks of different fertilizer and irrigation regimes had no effect on the amount of soluble proteins in leaves.

\section{Discussion}

Growth of all cultivars was similarly affected by fertilizer and irrigation treatments. The lowest fertilizer treatment ( 80 mg N/liter) produced commercially unacceptable plants with smaller leaf area, proportionally bigger stems, and chlorotic foliage. Doubling the fertilizer concentration to $160 \mathrm{mg} \mathrm{N} / \mathrm{liter}$ eliminated the chlorosis and resulted in an attractive green foliage,

Fig. 3. Relationship between chlorophyll content of six poinsettia cultivars as determined by extraction or nondestructively with a SPAD-502chlorophyll meter. Best fit regressionns were Angelika White- $y=11.298$ SPAD, $R^{2}=0.98$; Supjibi Red-y $=9.831$ SPAD,$R^{2}$ $=0.98 ;$ Celebrate $2-\mathrm{y}=5,735 \mathrm{SPAD}+0.107 \mathrm{SPAD}^{2}$ $R^{2}=0.98 ;$ Lilo Red-y $=4,911 \mathrm{SPAD}+0.169$ $\mathrm{SPAD}^{2}, R^{2}=0.98$; Freedom Red-y $=0.313 \mathrm{SPAD}^{2}$, $R^{2}=0.96$; Red Sails: $\mathrm{y}=0.330 \mathrm{SPAD}^{2}, R^{2}=0.96$. the intensity of which characteristically varies by cultivar. Our results are in agreement with previous studies indicating that acceptable poinsettias can be grown with up to 5070 less fertilizer than the recommended $250 \mathrm{mg}$ N/liter (Rose and White, 1994; Yelanich and Biernbaum, 1993, 1994).

Deficit irrigation reduced plant height with a similar reduction in the low and high fertilization treatments, but a disproportionate decrease at the medium fertilizer treatment. Other negative side effects of low irrigation were the considerable reductions in leaf area and lest' and stem growth, resulting in a relatively sparse canopy. Lieth and Burger (1989), using a soil-moisture tensionbased irrigation system with preset soil moisture levels, determined that chrysanthemums (Chrysanthemum morifolium Ramat.) experiencing low soil moisture levels between irrigations without leaching grew less leaf, stem, and shoot biomass compared to plants grown with daily irrigation and leaching. In the experiment described here, presumably by affecting carbohydrate allocation, low fertilizer rates resulted in proportionally larger stems and lower leaf biomass compared to the medium and high fertilizer treatments. Ratio of leaf to stem dry weight was $3 / 2$ for the low and $7 / 3$ for the medium and high fertilizer treatments.

Reduced shoot growth and reduction in stomata] conductance and transpiration at low irrigation were most likely due to the total amount of $\mathrm{N}$ applied and the leachate fraction. Only half the amount of total $\mathrm{N}$ was applied to the plants under the low deficit
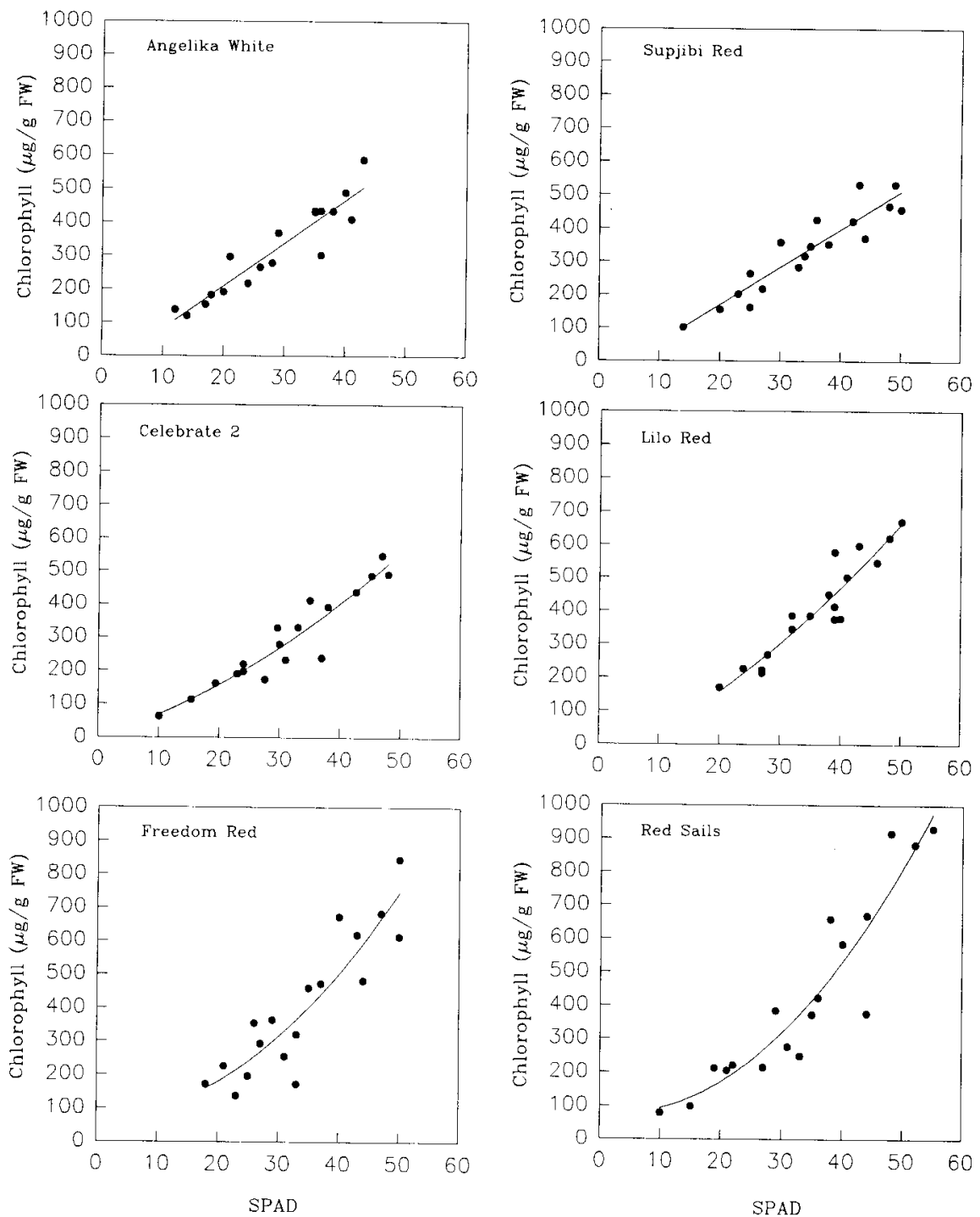
Table 4. Chlorophyll SPAD measurements of six poinsettia cultivars grown at three fertilizer and two irrigation treatments from 2 July until I Sept.

\begin{tabular}{|c|c|c|c|c|}
\hline & \multicolumn{4}{|c|}{ Chlorophyll SPAD } \\
\hline & \multicolumn{4}{|c|}{ Weeks after treatments begun } \\
\hline & 3 & 5 & 6 & 7 \\
\hline \multicolumn{5}{|l|}{ Fertilizer (mg N/liter) } \\
\hline 80 & 25.7 & 25.8 & 26.5 & 29.2 \\
\hline 160 & 34.2 & 36.2 & 37.8 & 36.9 \\
\hline 240 & 37.0 & 38.4 & 38.4 & 37.9 \\
\hline \multicolumn{5}{|l|}{ Irrigation (ml/pot) } \\
\hline 120 & 32.9 & 34.6 & 34.9 & 35.1 \\
\hline 240 & 31.8 & 32.2 & 33.6 & 34.1 \\
\hline \multicolumn{5}{|l|}{ Cultivar } \\
\hline Angelika White & $29.3 c^{7}$ & $33.5 \mathrm{bc}$ & $34.1 \mathrm{bc}$ & $33.5 \mathrm{bc}$ \\
\hline Celebrate 2 & $33.1 \mathrm{bc}$ & 31.1. c & $32.0 \mathrm{c}$ & $32.4 \mathrm{c}$ \\
\hline Freedom Red & $33.4 \mathrm{ab}$ & $33.8 \mathrm{~b}$ & $35.0 \mathrm{~b}$ & $35.1 \mathrm{~b}$ \\
\hline Lilo Red & $36.9 \mathrm{a}$ & $37.7 \mathrm{a}$ & $39.2 \mathrm{a}$ & $38.8 \mathrm{a}$ \\
\hline Red Sails & $30.3 \mathrm{bc}$ & $31.1 \mathrm{c}$ & $31.9 \mathrm{c}$ & $33.7 \mathrm{bc}$ \\
\hline Supjibi Red & $30.8 \mathrm{bc}$ & $33.5 \mathrm{bc}$ & $33.0 \mathrm{bc}$ & $34.4 \mathrm{bc}$ \\
\hline \multicolumn{5}{|l|}{ Significance of $F$ test } \\
\hline Fertilizer $(\mathrm{F})$ & $* * *$ & $* * *$ & $* * *$ & $* * *$ \\
\hline Irrigation (I) & NS & $* *$ & NS & NS \\
\hline $\mathrm{F} \times \mathrm{I}$ & NS & NS & NS & NS \\
\hline Cultivar (C) & $* * *$ & $* * *$ & $* * *$ & $* * *$ \\
\hline $\mathrm{F} \times \mathrm{C}$ & NS & NS & NS & $* *$ \\
\hline $\mathrm{I} \times \mathrm{C}$ & NS & NS & NS & NS \\
\hline $\mathrm{F} \times \mathrm{I} \times \mathrm{C}$ & NS & NS & NS & NS \\
\hline \multicolumn{5}{|c|}{ Single degree of freedom contrasts: } \\
\hline F linear & $* * *$ & $* * *$ & $* * *$ & $* * *$ \\
\hline F quadratic & $*$ & $* * *$ & $* * *$ & $* *$ \\
\hline $\mathrm{I} \times \mathrm{F}$ linear & NS & NS & NS & NS \\
\hline $\mathrm{I} \times \mathrm{F}$ quadratic & NS & NS & NS & NS \\
\hline
\end{tabular}

${ }^{\overline{ }}$ Means within a column followed by different letters are significantly different at $P<0.05$, Duncan's multiple range test.

${ }^{\text {NS }, * * *, * * t}$ Nonsignificant or significant at $P<0.05,0.01$, or 0.001 , respectively.

irrigation compared to the plants under high irrigation at respective fertilizer treatments. Total $\mathrm{N}$ applied was 298,595 , and $893 \mathrm{mg}$ at low irrigation and 595, 1190, and $1786 \mathrm{mg}$ at high irrigation for low, medium, and high fertilizer treatments, respectively. The leaching fraction was not measured in this experiment, but we observed runoff from both irrigation treatments and assume that plants under deficit irrigation also had lower leaching fractions. Previous studies reported no difference in shoot dry weight when poinsettias were fertilized with $300 \mathrm{mg} \mathrm{N} / \mathrm{liter}$ and were grown without leaching, resulting in a medium with an EC as high as 8.9 $\mathrm{dS} \cdot \mathrm{m}^{-1}$ compared to plants grown with leaching (Ku and Hershey, 1991). Yelanich and Biernbaum ( 1993) found highest medium EC with fertilization of $400 \mathrm{mg} \mathrm{N} /$ liter and no leaching, but obtained maximum shoot growth with fertilizer concentrations of 100 or $200 \mathrm{mg} \mathrm{N} /$ liter and leaching fractions of 0.55 . These results indicate that even if EC increased, poinsettias are extremely tolerant to a high medium EC and with the fertilizer concentrations used in our study a growth inhibition is not expected. Rather it appears that the irrigation management and the fact that media was allowed to dry out until water became unavailable and wilting occurred was responsible for reduced shoot growth. We suggest that growth inhibition under low irrigation and $80 \mathrm{mg}$ N/liter fertilization could be attributed to an insufficient supply of nutrients, which is corroborated by the smaller leaf area, chlorotic foliage, and deficient leaf $\mathrm{N}$ at both low and high irrigation. Although growth was inhibited considerably by the low irrigation treatment, leaf chlorophyll content was rarely affected (Table 4), indicating that the water stress was mild enough to avoid damage to the chloroplasts (Kramer, 1983).

At medium and high fertilization, plants received adequate nutrients, which is evident from the leaf $\mathrm{N}$ concentration and biomass production of all shoot components in the high irrigation treatment. The frequent drought of plants receiving the low irrigation treatment probably prevented uptake of nutrients that were in solution and available to the plant only for a short time. Additionally, precipitation of salts during the drought period may have damaged uptake sites of the root system. We suggest that high EC in the media can be tolerated by plants as long as the salts are in solution, but that high or even moderate EC may damage root hairs once the moisture in the media falls below a certain threshold. Similar conclusions were suggested from a study where chrysanthemum growth declined with increasing soil moisture tensions (Kiehl et al., 1992).

Nondestructive chlorophyll measurements required a calibration curve with extracted chlorophyll content for each cultivar. Leaves of 'Freedom Red' and 'Red Sails' had a higher chlorophyll content with increasing SPAD readings compared to the other cultivars. For example, at a SPAD reading of 45 , chlorophyll content of leaves from 'Red Sails' and 'Freedom Red' would be equivalent to 668 and $634 \mu \mathrm{g} \cdot \mathrm{g}^{-1}$ fresh weight (FW), those from 'Celebrate 2' and 'Supjibi Red' 474 and $563 \mu \mathrm{g} \cdot \mathrm{g}^{-1} \mathrm{FW}$, and those from 'Angelika White' and 'Lilo Red' would amount to 508 and 
$566 \mu \mathrm{g} \cdot \mathrm{g}^{-1} \mathrm{FW}$, respectively. Species differences in leaf greenness based on SPAD-501 measurements and chlorophyll content extraction had been determined previously (Marquard and Tipton, 1987; Yadava, 1986), but to our knowledge no calibration curves for cultivars have been established.

Leaf $\mathrm{N}$ of plants from all cultivars fertilized with $80 \mathrm{mg} \mathrm{N} / \mathrm{liter}$ was below the minimum recommended normal range of $4.0 \%$ (Ecke et al., 1990) and visually appeared deficient. For plants receiving 160 or $240 \mathrm{mg} \mathrm{N} /$ liter, leaf $\mathrm{N}$ ranged from $4.1 \%$ to $4.9 \%$. Increasing fertilization from 80 to $160 \mathrm{mg}$ N/liter increased both leaf $\mathrm{N}$ and leaf chlorophyll content. Increasing $\mathrm{N}$ to $240 \mathrm{mg} / \mathrm{liter}$ resulted in cultivar specific responses. As the $\mathrm{N}$ rate increased, leaf

Fig. 4. SPAD chlorophyll in leaf tissue of six poinsettia cultivars grown for 9 weeks under three fertilizer by two irrigation regimes, averaged over irrigation regimes (bars indicate \pm 1 standard error).
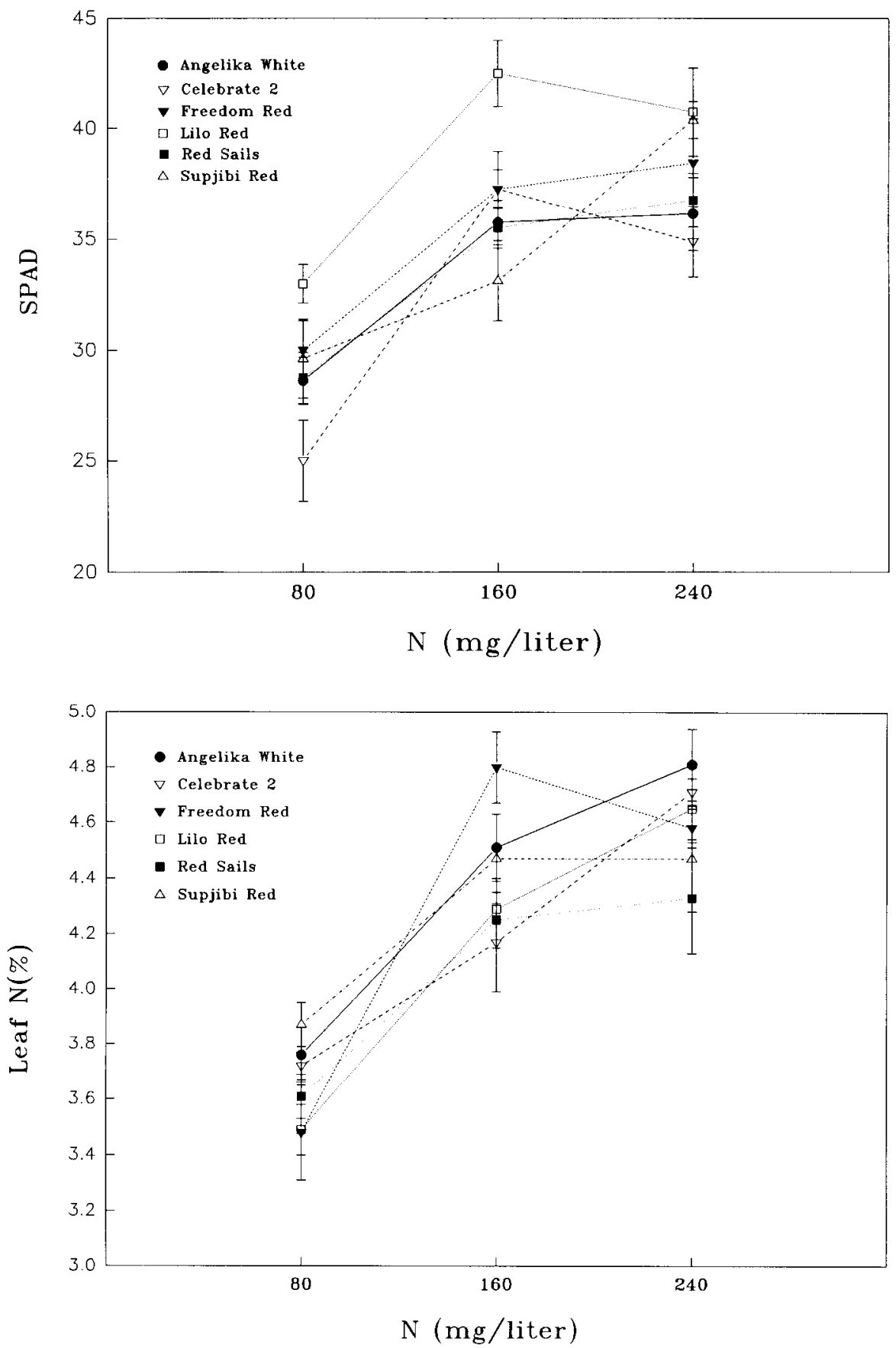

chlorophyll content of 'Supjibi Red' increased and leaf N concentration of 'Celebrate 2' and 'Angelika White' increased. Further research is needed to determine whether in situ chlorophyll content measurements can be useful to predict leaf $\mathrm{N}$ for possible adjustment of fertilizer applications during the production period.

Soluble foliar protein content was unaffected by irrigation and fertilizer treatments, but was cultivar specific. Although the cultural treatments did not alter soluble foliar protein content, they affected survivorship and development time of the silverleaf whitefly (Bemisia argentifolii Bellows \& Perring). Low irrigation significantly reduced insect survivorship and low fertilizer treatment decreased insect development time (R.A. Redak, unpublished data).

Stomatal conductance responded consistently to fertilizer treatments, but was more variable in response to irrigation and cultivar. Higher transpiration and conductance of plants receiving the lowest fertilizer treatment, especially at week 6 and 7 suggest that these plants suffered from a loss of stomatal control in response to the nutrient deficit. Contrasting evidence exists regarding the role of mineral deficiencies on stomatal behavior. Early studies found that nitrogen deficient plants reduced responsiveness of stomata to water stress (Kramer, 1983). Radin et al. (1991) reported that stomatal conductance and transpiration rates of mature cotton (Gossypium hirsutum L.) leaves were unaffected by N. Similarly, Bennett et al. ( 1986) found a treatment effect in well-watered corn (Zea mays L.) to $\mathrm{N}$ stress. Contrasting studies show that $\mathrm{N}$ deficiency caused early stomatal closure under water stress and is due to increased root resistance that lowers leaf water potential (Radin and Boyer, 1982).

Under the conditions of this study acceptable poinsettias could be grown with $160 \mathrm{mg}$ N/liter continuous fertilizer application and irrigation volumes of $240 \mathrm{ml}$ every other day. A further increase in fertilizer concentration is unwarranted because it showed no benefit for shoot biomass production or plant quality as expressed in foliage color. 'Supjibi Red' was the only cultivar where leaf chlorophyll content increased in response to increasing fertilizer from 160 to $240 \mathrm{mg} \mathrm{N} /$ liter. If a darker foliage color were desired for this cultivar, nitrogen-use efficiency could be increased by decreasing the leaching fraction or by applying nutrients based on plant uptake (Rose et al., 1994; Yelanich and Biernbaum, 1993).

\section{Literature Cited}

Bennett, J. M., J.W, Jones, B. Zur, and L.C. Hammond. 1986. Interactive effects of nitrogen and water stresses on water relations of

Fig. 5. Nitrogen concentration in leaf tissue of six poinsettia cultivars grown for 9 weeks under three fertilizer by two irrigation regimes, averaged over irrigation regimes (bars indicate \pm 1 standard error). 
field-grown corn leaves. Agron. J. 78:273-280.

Bentz, J., J. Reeves III., P. Barbosa, and B. Francis. 1995. Within-plant variation in nitrogen and sugar content of poinsettia and its effects on the oviposition pattern, survival, and development of Bemisia argentifolii (Homoptera: Aleyrodidae). Population Ecology 24:271-277.

Biernbaum, J.A. 1992, Root-zone management of greenhouse containergrown crops to control water and fertilizer use. HortTechnology 2:127132.

Bruinsma, J. 1963. The quantitative analysis of chlorophylls a and b in plant extracts. Photochem. Photobiol. 2:241-249.

Cabrera, R. I., R.Y. Evans, and J.L. Paul. 1993. Leaching losses of N from container-grown roses. Scientia Hort. 53:333-345.

Ecke, P., Jr., O.A. Matkin, and D.E. Hartley. 1990. The Poinsettia Manual. 3rd ed. Paul Ecke Poinsettias. Encinitas, Calif.

Hershey, D.R. and J.L. Paul. 1982. Leaching-losses of nitrogen from pot chrysanthemums with controlled-release or liquid fertilization. Scientia Hort. 17:145-152.

Jones, C.G.. J.D. Hare, and S.J. Compton. 1988. Measuring plant protein with the Bradford assay. 1. Evaluation and standard method. J. Chem. Ecol. 15:979-992.

Kiehl, P.A., J.H. Lieth, and D.W. Burger. 1992. Growth response of chrysanthemum to various container medium moisture tension levels. J. Amer. Soc. Hort. Sci. 117:224-229.

Kramer, P.J. 1983. Water relations of plants. Academic Press, Orlando. Fla.

Ku, C.S.M, and D.R. Hershey. 1991. Leachate electrical conductivity and growth of potted poinsettia with leaching fractions of 0 to 0.4. J. Amer. Soc. Hort. Sci. 116:802-806.

Larson, R.A. 1992. Introduction to floriculture. 2nd ed. Academic Press, New York,

Lieth, J.H. and D.W. Burger. 1989. Growth of chrysanthemum using an irrigation system controlled by soil moisture tension. J. Amer. Soc. Hort. Sci. 114:387-392.

Marquard, R.D. and J.L. Tipton. 1987. Relationship between extractable chlorophyll and an in situ method to estimate leaf greenness. HortScience 22:1327.
Matkin O.A. and P.A. Chandler. 1957. UC type soil mixes for containergrown plants. Calif. Agr. Expt. Sta, Ext. Serv. Leaflet 89.

Mattson, W.J. and R.A. Haack, 1987a, The role of drought in outbreaks of plant-eating insects. Bioscience 37:110-118.

Mattson, W.J. and R.A. Haack. 1987b. The role of drought stress in outbreaks of phytophagous insects, p. 365-407. In: P. Barbosa and J. Schultz (eds.). Insect outbreaks. Academic Press. New York.

Radin, J.W. and J.S. Boyer. 1982. Control of leaf expansion by nitrogen nutrition in sunflower plants. Role of hydraulic conductivity and turgor. Plant Physiol. 69:771-775.

Radin, J.W., J.R. Mauney, and P.C. Kerridge. 1991. Effects of nitrogen fertility on water potential of irrigated cotton. Agron. J. 83:739-743.

Röber R. and M. Hafez. 1981. The influence of different water supply upon the growth of chrysanthemums. Acta Hort. 125:69-78.

Rose. M.A. and J.W. White. 1994. Nitrogen rate and timing of nitrogen application in poinsettia (Euphorbia pulcherrima Willd. Ex Klotz.). HortScience 29:1309-1313.

Rose, M.A., J.W. White, and M.A. Rose. 1994. Maximizing nitrogen-use efficiency in relation to the growth and development of poinsettia. HortScience 29:272-276.

Tayama H.K. and S.A. Carver. 1992. Comparison of resin-coated and soluble fertilizer formulations in the production of zonal geranium, potted chrysanthemum, and poinsettia. HortTechnology 2:476-479.

White, T.C.R, 1976. Weather. food and plagues of locusts. Oecologia 22: $119-134$

White, T.C.R. 1984. The abundance of invertebrate herbivores in relation to the availability of nitrogen in stressed food plants. Oecologia 63:90105.

Yadava, U.L. 1986. A rapid and nondestructive method to determine chlorophyll in intact leaves. HortScience 21:1449-1450.

Yelanich M.V. and J.A. Biernbaum. 1994. Fertilizer concentration and leaching affect nitrate-nitrogen leaching from potted poinsettia. HortScience 29:874-875.

Yelanich M.V. and J.A. Biernbaum. 1993. Root-medium nutrient concentrations and growth of poinsettia at three fertilizer concentrations and four leaching fractions. J. Amer. Soc. Hort. Sci. 118:771-776. 